\title{
Obesity, diabetes and OSAS induce of sleep disorders: Exercise as therapy
}

\author{
Eduardo S Alves ${ }^{2}$, Fabio S Lira ${ }^{1,2}$, Ronaldo VT Santos ${ }^{2,3}$, Sergio Tufik ${ }^{1}$ and Marco T de Mello ${ }^{1,2^{*}}$
}

\begin{abstract}
Sleep is an integral part of good health. Sleep disorders and variations in sleep habits are associated with a lowgrade inflammatory status, which may be either a cause or consequence of other conditions, including obesity, diabetes and cardiovascular disease. Several strategies are available to counteract these conditions including continuous positive airway pressure (CPAP), pharmacological and nutritional interventions, and even surgery. At present, our group is investigating the effect of chronic endurance exercise on sleep alterations.
\end{abstract}

\section{Hypothesis}

Sleep deprivation is a common phenomenon in today's society. Over the last 50 years, daily sleep duration in adolescents and adults decreased by $1.5-2$ hours, and more than $30 \%$ of Americans between the ages of 30 to 64 years old report less than 6 hours of sleep per night [1]. Moreover, the quality of sleep decreases with age [2]. In addition, the prevalence of obstructive sleep apnea syndrome (OSAS), obesity, and cardiovascular and metabolic disease are increasing [3]. This is relevant because epidemiological studies report a positive correlation between decreased sleep time and increases in body mass index and diabetes prevalence $[4,5]$.

OSAS is a common disorder characterized by repetitive episodes of partial or complete obstruction of the upper airway during sleep and increased respiratory effort. This syndrome can lead to the development of obesity and diabetes $[6,7]$.

Different strategies are utilized to counteract OSAS, obesity and diabetes [8]. CPAP treatment exerts a beneficial effect on glucose metabolism and insulin resistance in people with OSAS [9]. However, when CPAP usage ceases the positive effects are abolished. Others therapies, such as drugs to aid weight loss and normalize insulin are often used to treat obesity and diabetes, respectively. Although these approaches target individual problems, we hypothesize that chronic endurance exercise may be an effective treatment for all three conditions.

\footnotetext{
* Correspondence: tmello@demello.net.br

'Departamento de Psicobiologia, Universidade Federal de São Paulo, Brazil Full list of author information is available at the end of the article
}

Our group has previously demonstrated the effects of acute and chronic exercise on sleep in both humans and rats [[10-12], unpublished]. Exercise training improves outcomes, including total adipose tissue and diabetes, and may ameliorate OSAS.

Confirming our hypothesis, Figure 1 shows that compared with conventional therapies, exercise training is a more effective strategy for counteracting OSAS, obesity and diabetes involved in the development of sleep disorders. However, additional studies are needed to elucidate the mechanism(s) of how exercise training improves sleep quality.

\section{Author details}

'Departamento de Psicobiologia, Universidade Federal de São Paulo, Brazil. ${ }^{2}$ Centro de Estudos em Psicobiologia e Exercício - CEPE, São Paulo, Brazil. ${ }^{3}$ Departamento de Biociências, Universidade Federal de São Paulo, Campus Baixada Santista, Brazil.

Received: 10 June 2011 Accepted: 23 August 2011

Published: 23 August 2011

\section{References}

1. Bonnet MH, Arand DL: We are chronically sleep deprived. Sleep 1995 , 18(10):908-11.

2. Van Cauter E, Leproult R, Plat L: Age-related changes in slow wave sleep and REM sleep and relationship with growth hormone and cortisol levels in healthy men. J Am Med Assoc 2000, 284(7):861-8.

3. Knutson KL: Sleep duration and cardiometabolic risk: a review of the epidemiologic evidence. Best Pract Res Clin Endocrinol Metab 2010, 24(5):731-43, Review.

4. Taheri $\mathrm{S}$, Lin L, Austin D, Young T, Mignot E: Short sleep duration is associated with reduced leptin, elevated ghrelin, and increased body mass index. PLoS Med 2004, 1:e62.

5. Hasler G, Buysse D, Klaghofer R, Gamma A, Ajdacic V, Eich D, Rossler W, Angst J: The association between short sleep duration and obesity in young adults: a 13-year prospective study. Sleep 2004, 27:661-666.

\section{C)




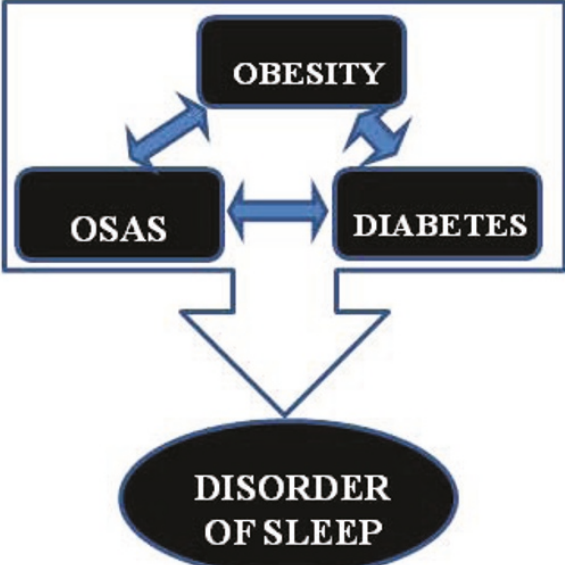

Figure 1a. Obesity, OSAS and Diabetes leads Disorders of Sleep.

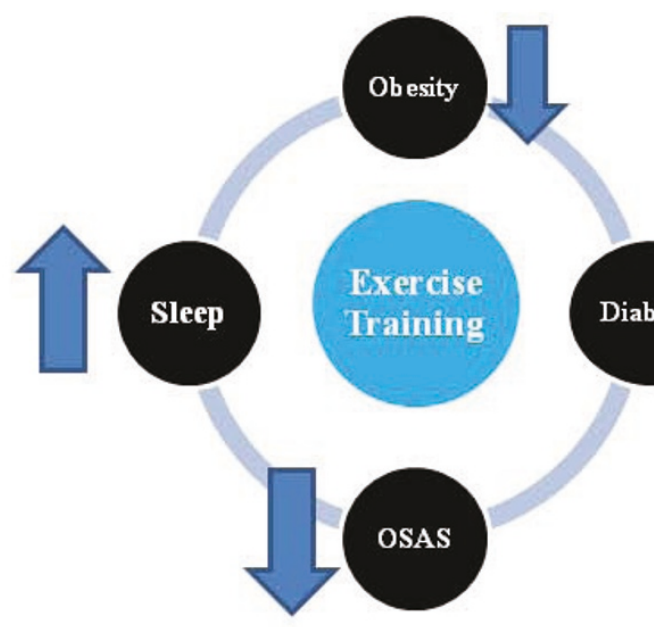

\section{Traditional \\ therapy}

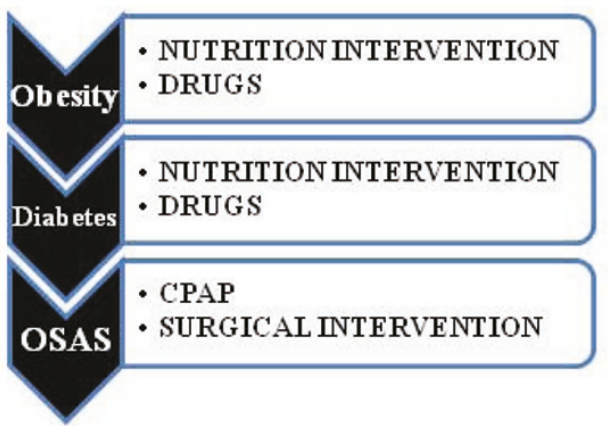

Figure 1b. Traditional therapy induces improvement in the Disorders of Sleep.

Figure 1 Exercise training compared with conventional therapies for counteracting OSAS, obesity and diabetes involved in the development of sleep disorders.

6. Schwartz AR, Patil SP, Squier S, Schneider H, Kirkness JP, Smith PL: Obesity and upper airway control during sleep. J Appl Physiol 2010, 108(2):430-5.

7. Pamidi S, Aronsohn RS, Tasali E: Obstructive sleep apnea: role in the risk and severity of diabetes. Best Pract Res Clin Endocrinol Metab 2010, 24(5):703-15.

8. Romero-Corral A, Caples SM, Lopez-Jimenez F, Somers VK: Interactions between obesity and obstructive sleep apnea: implications for treatment. Chest 2010, 137(3):711-9.

9. Steiropoulos P, Papanas N, Nena E, Maltezos E, Bouros D: Continuous positive airway pressure treatment in patients with sleep apnoea: does it really improve glucose metabolism? Curr Diabetes Rev 2010, 6(3):156-66.

10. Esteves AM, de Mello MT, Pradella-Hallinan M, Tufik S: Effect of acute and chronic physical exercise on patients with periodic leg movements. Med Sci Sports Exerc 2009, 41(1):237-42.

11. De Mello MT, Esteves AM, Tufik S: Comparison between dopaminergic agents and physical exercise as treatment for periodic limb movements in patients with spinal cord injury. Spinal Cord 2004, 42(4):218-21.

12. Lira FS, Pimentel GD, Santos RV, Oyama LM, Damaso AR, Oller do Nascimento CM, Viana VA, Boscolo RA, Grassmann V, Santana MG, Esteves AM, Tufik S, de Mello MT: Exercise training improves sleep pattern and metabolic profile in elderly people in a time-dependent manner. Lipids Health Dis 2011, 10(1):113.
doi:10.1186/1476-511X-10-148

Cite this article as: Alves et al:: Obesity, diabetes and OSAS induce of sleep disorders: Exercise as therapy. Lipids in Health and Disease 2011 10:148

\section{Submit your next manuscript to BioMed Central} and take full advantage of:

- Convenient online submission

- Thorough peer review

- No space constraints or color figure charges

- Immediate publication on acceptance

- Inclusion in PubMed, CAS, Scopus and Google Scholar

- Research which is freely available for redistribution 